\title{
Soil Fertility in Crop-Livestock System Subjected to Nitrogen Fertilization and Grazing
}

\author{
L. R. Sartor ${ }^{1}$, I. E. Sandini ${ }^{2}$, P. C. F. Carvalho ${ }^{3}$ \& B. E. S. Ruthes ${ }^{1}$ \\ ${ }^{1}$ Federal Technological University of Paraná, Dois Vizinhos, Paraná, Brazil \\ ${ }^{2}$ State University of Central West, Guarapuava, Paraná, Brazil \\ ${ }^{3}$ Federal University of Rio Grande do Sul, Porto Alegre, Rio Grande do Sul, Brazil \\ Correspondence: Laércio Ricardo Sartor, Federal University of Paraná, Estr. p/Boa Esperança, S/n-Zona Rura, \\ Dois Vizinhos, Paraná, Brazil. Tel: 46-3536-8900. E-mail: laerciosartor@utfpr.edu
}

Received: September 25, 2018

Accepted: November 2, 2018

Online Published: January 15, 2019

doi:10.5539/jas.v11n2p121

URL: https://doi.org/10.5539/jas.v11n2p121

\begin{abstract}
The aim of this study was to evaluate the effects of sheep grazing and increasing rates of nitrogen fertilization on oats + ryegrass at winter on the soil $\mathrm{K}, \mathrm{Ca}, \mathrm{H}+\mathrm{Al}, \mathrm{Mg}$ and $\mathrm{P}$ concentrations in a crop-livestock system with beans and corn crop succession during summer after four years (2006-2009) of the experiment establishment. Treatments consisted of different nitrogen levels $\left(0,75,150\right.$ and $\left.225 \mathrm{~kg} \mathrm{ha}^{-1}\right)$ with and without sheep grazing Lolium multiflorum Lam and Avena spp. Soil chemical traits were evaluated at depths of 0-5, 5-10, and 10-15 cm. The experiment was laid out as random block design in a split-plot scheme with three replications. Soil $\mathrm{K}$ content were higher at the superficial soil layer and at the treatment with $150 \mathrm{~kg} \mathrm{ha}^{-1} \mathrm{~N}$ and remained high along the four years of assessment. Animal grazing at winter results in better soil chemical traits in relation to the soil $\mathrm{Ca}$ and $\mathrm{H}+\mathrm{Al}$. There were no nutrient $(\mathrm{K}, \mathrm{Ca}, \mathrm{P}$ and $\mathrm{Mg}$ ) losses or extraction when under overgrazing, a fact that confirms the possibility of using animals in the crop-livestock areas without affecting its chemical traits. There was also an increase in Ca and SB concentrations with grazing, including in subsurface soil.
\end{abstract}

Keywords: beans, corn, season pasture, soil chemistry

\section{Introduction}

The integration of crop and livestock has beneficial effects such as optimization of the productivity of the property and improvement in soil quality over time (Entz et al., 2002). In the southern region of Brazil, the cultivation of winter cover crops, commonly oats and ryegrass (Fontaneli et al., 2011), aims to protect and conserve the soil, as well as the production of vegetal material in sufficient quantities for direct planting of summer cultures. Beyond that it can be used as a food source for ruminants (mainly cattle and sheep) in overgrazing, as an alternative source of income to the producer during the winter (Balbinot Jr. et al., 2008) and the direct and indirect participation of the animal in the nutrient cycling (Ferreira et al., 2011) in a crop-livestock system (CLS).

The nutrient dynamics in the soil are influenced by management (Santos et al., 2010) and the long-term evaluation of the production system is of great importance to verify its sustainability. The crop rotation and the presence of the animal in livestock farming integration systems can influence the chemical, physical and biological characteristics of the soil, desirable to a good development of plants and the preservation of biodiversity, which brings balance to the productive ecosystem. These factors provide the reduction of external inputs (fertilizers and chemicals) and make the production system more efficient. As regards nutrient cycling, the animal is actively involved in returning nutrients which were lost by the pasture, through their feces and urine (Cavalcante, 2011), it may represent up to $90 \%$ of the intake. These nutrients may be more readily available to the plant compared to the process of decomposition of vegetable matter without passing through the digestive tract of the ruminant.

Among the chemical attributes, it is observed that the presence of the animal characterizes the variation in the contents of the K (Ferreira et al., 2009), P, Ca and Mg (Flores et al., 2008) as well it may interfere with the potential acidity condition of the soil through the release of organic acids (Franchini et al., 2000) in the decomposition of animal waste, such as feces. In this sense, there are few studies that characterize soil chemical 
attributes in crop-livestock integration systems when the animal is present in overgrazing, and in the long term, which raises doubts about the behavior of these nutrients in the soil in this system.

Fertilization on pasture can mean higher animal production, due to the greater availability of forage, without however occurring nutrient extraction, since the presence of the animal determines low nutrient extraction due to its catalytic characteristic, which promotes the cycling of nutrients consumed by it. This work is based on the hypothesis that the CLS's do not reduce the nutrient content of the soil when compared to areas where forage is used as a cover crop, which allows higher yields, without impairing soil fertility.

The objective of this study was to evaluate the variation of $\mathrm{K}, \mathrm{P}, \mathrm{Ca}$, the relation $\mathrm{Ca}: \mathrm{Mg}, \mathrm{H}+\mathrm{Al}, \mathrm{pH}$ and $\mathrm{SB}$ levels in a crop-livestock integration system for four years after the establishment of the system, as a function of nitrogen rates in pasture of winter, with and without overgrazing and succession of corn and beans in the summer.

\section{Method}

The experiment was started in June 2006 in an area belonging to the Center for Educational and Technological Development of Guarapuava, PR-Brazil, part of to the State University of the Center-West (UNICENTRO), physiographic region of the Third Paranaense Plateau, latitude $25^{\circ} 33^{\prime} \mathrm{S}$, longitude $51^{\circ} 29^{\prime}$ West and $1095 \mathrm{~m}$. The soil is classified as a combination of the Brown Latosol (Haplohumox) soft waved relief, substrate of Trapp spill rocks both with prominent A (EMBRAPA, 2013) clayey texture $\left(0.624 \mathrm{~kg} \mathrm{~kg}^{-1}\right.$ clay, $0.311 \mathrm{~kg} \mathrm{~kg}^{-1}$ silt and 0.080 $\mathrm{kg} \mathrm{kg}^{-1}$ of sand). The climate, according to the classification of KÖPPEN, is Cfb type (Alvares et al., 2013). The annual precipitation varies from 1,400 to $1,800 \mathrm{~mm}$ and the months of April and May are the driest.

Before the implementation of the crop-livestock system on April of 2006, the experimental area was used in a direct planting system and in the previous Summer (2005/2006) with corn production for silage after Winter fallow. From 2006 on, the area has been used for the cultivation of white oats (Avena sativa), common black oats (Avena strigosa) and common ryegrass (Lolium multiflorum) in winter, and in sequence maize and beans in the summer.

This experiment consists in a delimitation of random blocks in subsubdivided plots within three repetitions. In the main plots there were allocated nitrogen levels of $0,75,150$ and $225 \mathrm{~kg} \mathrm{ha}^{-1}$ (urea with $45 \%$ nitrogen), casualizing subdivisions with and without grazing in the main plots and the depth factor casualized without subsubparcels. In each main plot, an area of $96 \mathrm{~m}^{2}$ was isolated from grazing and the rest grazed with Ile de France sheep in continuous stocking with variable stocking rate and maintained the average height of the canopy of plants at $14 \mathrm{~cm}$.

The sowing of the Winter crops was made in direct planting system with spacing of $17 \mathrm{~cm}$. In these cultures, 60 $\mathrm{kg} \mathrm{ha}^{-1} \mathrm{P}_{2} \mathrm{O}_{5}$ and $60 \mathrm{~kg} \mathrm{ha}^{-1}$ of $\mathrm{K}_{2} \mathrm{O}$ were used as fertilizing base in cover and in amount of $\mathrm{N}$ applied as a function of the treatments described above.

About 20 to 30 days before sowing corn or beans (according to year of cultivation) the animals were removed from the area, with subsequent desiccation of the pasture using $2.5 \mathrm{~L} \mathrm{ha}^{-1}$ of glyphosate. After this period the corn (Zea mays) or bean (Phaseolus vulgaris) were sown in sequence. For corn, $\mathrm{P}$ and $\mathrm{K}$ fertilization were applied to the haul before sowing, at dosages of $100 \mathrm{~kg} \mathrm{ha}^{-1}$ of $\mathrm{P}_{2} \mathrm{O}_{5}$ and $100 \mathrm{~kg} \mathrm{ha}^{-1}$ of $\mathrm{K}_{2} \mathrm{O}$, the sources being the triple superphosphate $\left(41 \%\right.$ soluble $\left.\mathrm{P}_{2} \mathrm{O}_{5}\right)$ and $\mathrm{K}$ chloride $\left(60 \%\right.$ soluble $\left.\mathrm{K}_{2} \mathrm{O}\right)$, respectively. After the emergence of the crop, the nitrogen was applied to the haul in the amount of $150 \mathrm{~kg} \mathrm{ha}^{-1}$. The source used was urea $(45 \% \mathrm{~N})$.

For the beans crop the soil fertilization was performed with $100 \mathrm{~kg} \mathrm{ha}^{-1}$ of $\mathrm{P}_{2} \mathrm{O}_{5}$, the source being the triple superphosphate as source of $\mathrm{P}$, and $190 \mathrm{~kg} \mathrm{ha}^{-1}$ of $\mathrm{K}_{2} \mathrm{O}$ being the source the chloride of $\mathrm{K}$. The nitrogen applied in the dosage of $120 \mathrm{~kg} \mathrm{ha}^{-1}$. Weed, pest and disease control were carried out throughout the summer crop cycle.

In each year, after the summer cultivation (corn or beans) and before the winter cultivation (oats and ryegrass), in the period of May, 2006, April 2007, 2008 and 2009, samples were collected in eight (8) points per experimental unit, defined so that each year the collections were made close to these, soil subsamples with the aid of a tract in order to compose a set of samples of the depths of 0-5, 5-10 and 10-15 cm of each treatment imposed under the winter crop (doses of nitrogen vs with and without overgrazing).

The samples were sent to the analytical laboratory TECSOLO - Guarapuava - PR where the amounts of K, P and $\mathrm{Ca}$ were determined. $\mathrm{K}$ was extracted with the double acid solution (Mehlich-1) and determined in the flame photometer; $\mathrm{Ca}$ and $\mathrm{Mg}$ were extracted with $1 \mathrm{~mol} \mathrm{KCl} \mathrm{L}^{-1}$ and determined by atomic absorption spectrometry. 
The results were subjected to analysis of variance by the $\mathrm{F}$ test at a significance level of $5 \%$ of probability using the statistical package Statistic Analysis System (SAS, 2002) and later, when they presented significance, the means of qualitative effect were compared by the test Tukey at $5 \%$ probability. For the results of quantitative effect, regression studies were performed considering the highest significant degree.

\section{Results and Discussion}

In the implementation of the livestock husbandry integration experiment in 2006 (Figure 1), the K amounts were more concentrated in the soil surface $(0-5 \mathrm{~cm}$ depth), maintaining this behavior in the four years of evaluation. The effect characterized as direct planting system, where the nutrients tend to concentrate due to the slightest tilting of the soil, especially in the depth of 0 to $10 \mathrm{~cm}$ (Pariz et al., 2011; Cavalcante et al., 2007; Zanão Junior et al., 2010).

In the year of 2008 (Figure 1) the concentrations of K decreased considerably, an effect that can be attributed to the export of $\mathrm{K}$ by the corn crop, which, when observed in this work, is higher than in the bean culture. With the successive crops of forage species (oats + ryegrass) in the Winter, plus the succession of beans or corn in the Summer, the concentrations of K returned to the soil in 2009 (Figure 1) in a concentration compatible with those obtained in the beginning of the study, due to the contribution of potassium fertilization during successive cultivation according to soil analysis and by potential contribution of forage species when used as cover in soil nutrient extraction and cycling in crop rotation systems (Castoldi et al., 2012).

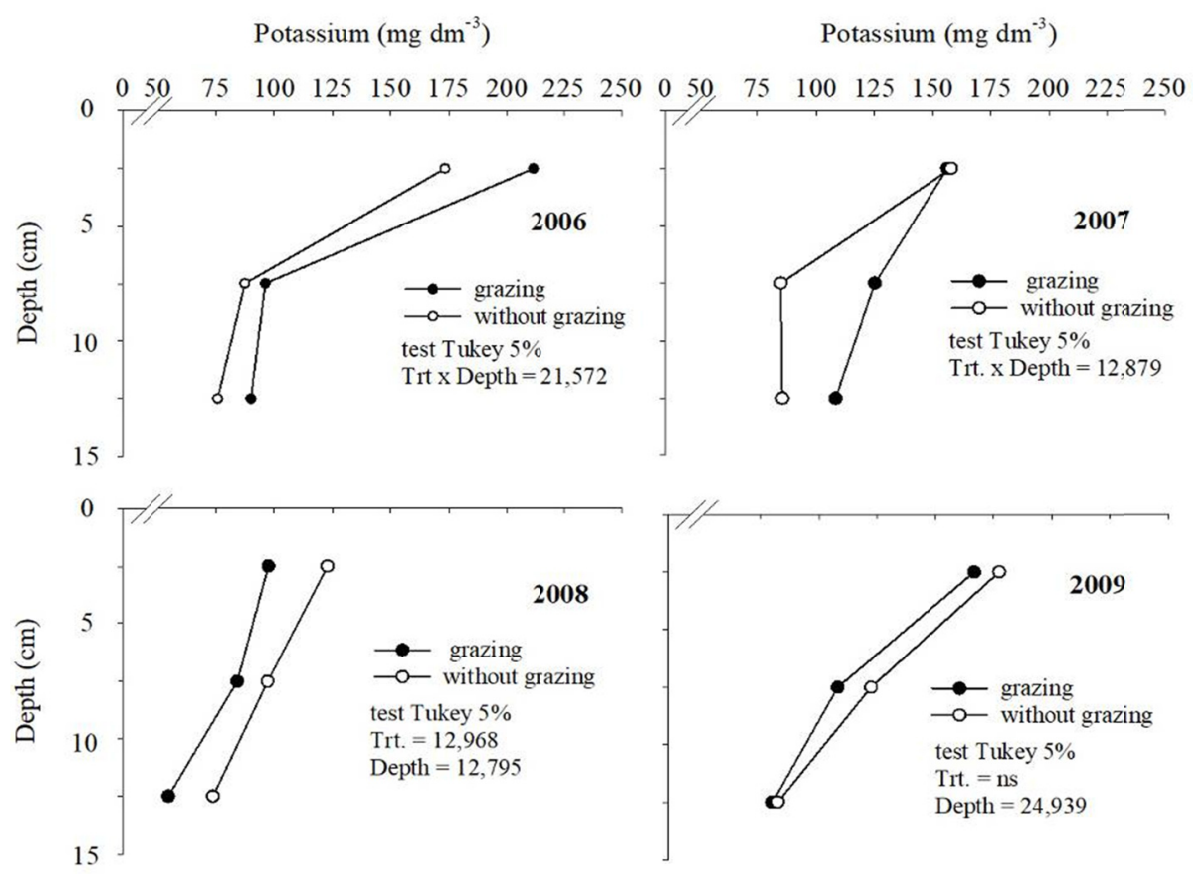

Figure 1. Concentration of $\mathrm{K}\left(\mathrm{mg} \mathrm{dm}^{-3}\right)$ in Crop-Livestock System according to whether or not grazing (Trt.) was used in winter and depth $(0-5,5-10$ and 10-15 cm) in the years 2006, 2007, 2008 and 2009. Guarapuava, PR

There was an influence of overgrazing by sheep on $\mathrm{K}$ concentration amounts in the soil (Figure 1). In the implementation of the experiment, the $\mathrm{K}$ was superior in the overgrazing areas when compared to the areas without it, and in the following years there was an inversion in the $\mathrm{K}$ concentrations amounts in the soil, being the higher K contents found in the areas without overgrazing in the year of 2008. However, in 2009 when comparing the treatments with and without overgrazing, the differences for the contents of $\mathrm{K}$ were observed only related to depth.

There is evidence that $\mathrm{K}$ displacement occurred for layers below $15 \mathrm{~cm}$ considering the years 2007 and 2008 (Figure 1) in overgrazing areas, with a decrease from $108 \mathrm{mg} \mathrm{dm}^{-3}$ to $54 \mathrm{mg} \mathrm{dm}^{-3}$ from year by year, a more pronounced difference than areas without the overgrazing, and the values increased from $85 \mathrm{mg} \mathrm{dm}^{-3}$ to $73 \mathrm{mg}$ $\mathrm{dm}^{-3}$. Ferreira et al. (2011) observed accumulation of $\mathrm{K}$ in the animal concentration areas, as Souto (2006) reports possible leaching of $\mathrm{K}$ in areas of intense grazing. The decrease in concentrations of $\mathrm{K}$ from the year 
2007 to 2008 were also observed in the more superficial layers suggesting the greater extraction of the nutrient by the corn crop.

Another important factor is that overgrazing areas showed higher grains yields of $585 \mathrm{~kg} \mathrm{ha}^{-1}$ compared to grazing areas (Andreolla, 2010), resulting in greater export of nutrients by corn crop in this system, not considering important the export of this nutrient by the animal. However, Sandini et al. (2011) did not observe overgrazing effects on maize productivity in this same work, evidencing that there was no difference in nutrient extraction between grazing and non-grazing areas. For beans cultivation during 2006/2007 crops, the difference between with and without grazing was $75 \mathrm{~kg} \mathrm{ha}^{-1}$ (Andreolla, 2010), a smaller difference compared to corn. Also, the influence of nitrogen rates on $\mathrm{K}$ concentration in all evaluated years was observed, with the application of $150 \mathrm{~kg} \mathrm{ha}^{-1}$ the highest concentrations of nutrient in the soil were obtained (Figure 2). However, the $\mathrm{N}$ rates applied in the winter pasture did not influence the $\mathrm{Ca}$ and $\mathrm{H}+\mathrm{Al}$ concentrations.

The fact that higher $\mathrm{N}$ doses led to a lower accumulation of $\mathrm{K}$ in the soil may be due to the higher animal load in the condition of greater fertilization of the pasture $\left(225 \mathrm{~kg} \mathrm{ha}^{-1}\right.$ of N) coupled with the higher grain yield in the summer considering the residual effect of $\mathrm{N}$ applied in the winter to the summer crop as found by Andreolla (2010) in this same work, as well as also observed by Assmann et al. (2003) in a similar experiment. Ferreira et al. (2009) evaluated the concentration of $\mathrm{K}$ in a crop integration system in different grazing intensities in black oat + ryegrass pasture, observed lower concentrations of $\mathrm{K}$ at the management height of the $10 \mathrm{~cm}$ pasture, which had the highest animal load, attributing it to possible losses, once the $\mathrm{K}$ returns around $90 \%$ by the urine of which is ingested by the animal (Whitehead, 2000; Vendramini et al., 2014) and in the ionic form it will be more easily absorbed by the plant (Parente et al., 2016) as well as being more prone to losses due to leaching or erosion, because the $\mathrm{K}$ is water soluble under these conditions (Ceretta et al., 2002).

However, there were no significant reductions in soil $\mathrm{K}$ concentration amount in the $0-15 \mathrm{~cm}$ layer to the extent of being detrimental to crop development, taking into account the collection after Summer crop harvesting. $\mathrm{K}$ weed leaching is usually low due to animal load and root system, especially grasses, as noted by Kayser \& Isselstein (2005), but high levels of $\mathrm{K}$ available in the soil and high $\mathrm{K}$ input via fertilizer or urine lead to losses.

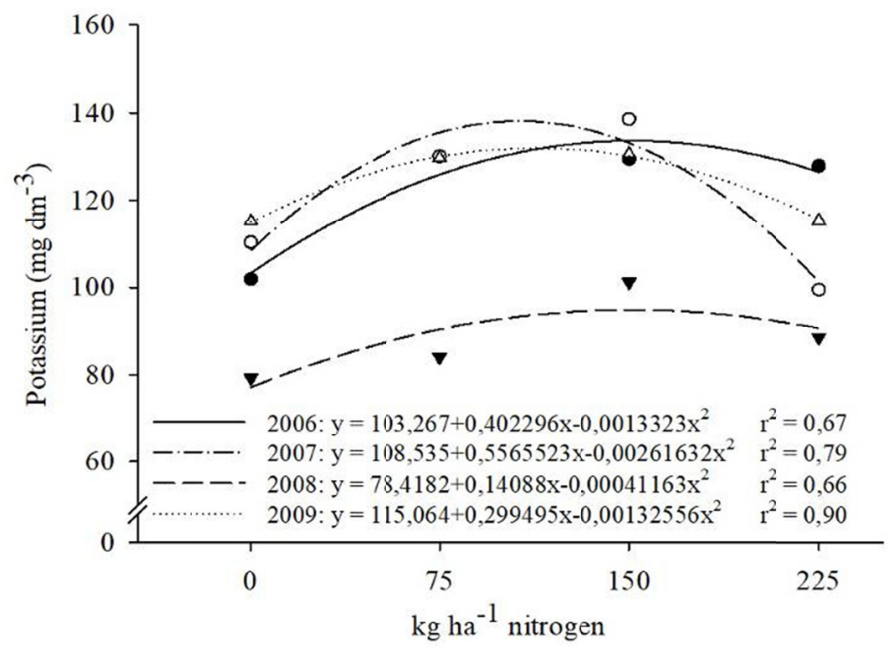

Figure 2. Concentration of $\mathrm{K}\left(\mathrm{mg} \mathrm{dm}^{3}\right)$ in soil in a crop-livestock integration system as a function of nitrogen doses in the winter pasture during four years of evaluation, Guarapuava, PR

The concentration amount of P (Figure 3) presented little variation among the factors involved, with differences in the depths of sampling, but without significant differences for the years of 2006, 2007 and 2008 by the use or absence of grazing. Also, Santos et al. (2003) observed higher P accumulation in direct planting and different production systems, using forage and grain-producing species. 


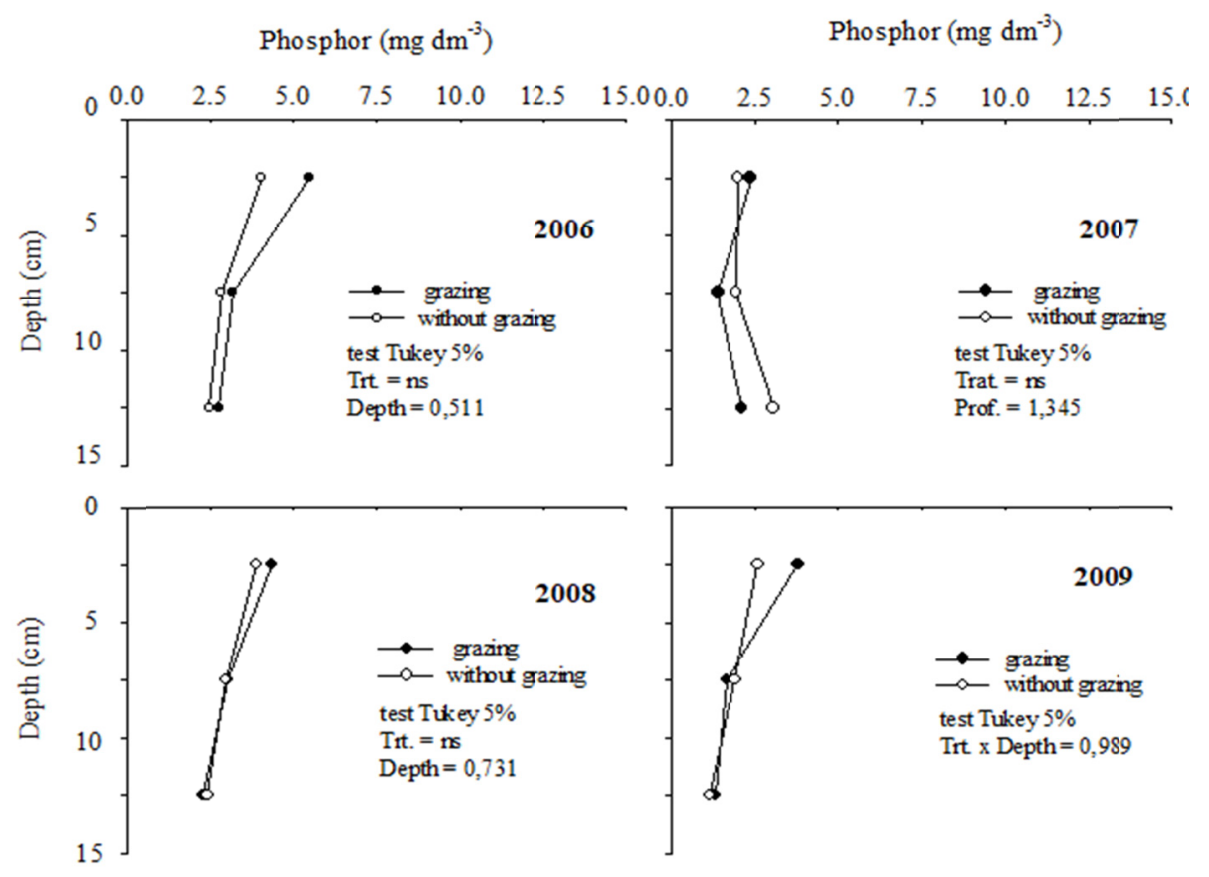

Figure 3. Concentration of $\mathrm{P}\left(\mathrm{mg} \mathrm{dm}^{-3}\right)$ in a Crop-Livestock System farming according to whether or not grazing (Trt) was used in winter and depth $(0-5,5-10$ and 10-15 cm) in the years 2006, 2007, 2008 and 2009.

Guarapuava, PR

The differences for overgrazing and without it were observed only in the year of 2009 and the slightly expressive variations are mainly due to the low levels of $\mathrm{P}$ in the soil. The accumulation of extractable $\mathrm{P}$ at the soil surface layer results from surface applications in the direct planting system (Nunes et al., 2011), from the release during the decomposition of plant and animal residues (Sidiras \& Pavan, 1985).

The levels of $\mathrm{H}+\mathrm{Al}$ were also uniform at the beginning of the experiment and were higher in the areas without overgrazing in the years 2007 and 2009 (Figure 4). Related to depth the values differed only in the year of 2009 and although without interaction, there is a greater difference, in that year, between the areas with and without grazing in the $5-15 \mathrm{~cm}$ layer for $\mathrm{H}+\mathrm{Al}$. Several mechanisms may be involved in the change of soil acidity in subsurface layers, especially when applied to the surface calcareous, as in this study and in the direct planting system (Caires et al., 2000; Flores et al., 2008). However, pH was little influenced by the treatments. Only in 2007 there was a significant $\mathrm{pH}$ superiority in overgrazing areas in relation to those without it (Ciotta, 2004). As well as organic residues play a fundamental role (Sidiras \& Pavan, 1985) in the correction of the acidity in the deeper layers, which can be optimized by the overgrazing losses of sheep, as observed by Flores et al. (2008) when the presence of grazing cattle increased the depth effect of surface liming. 


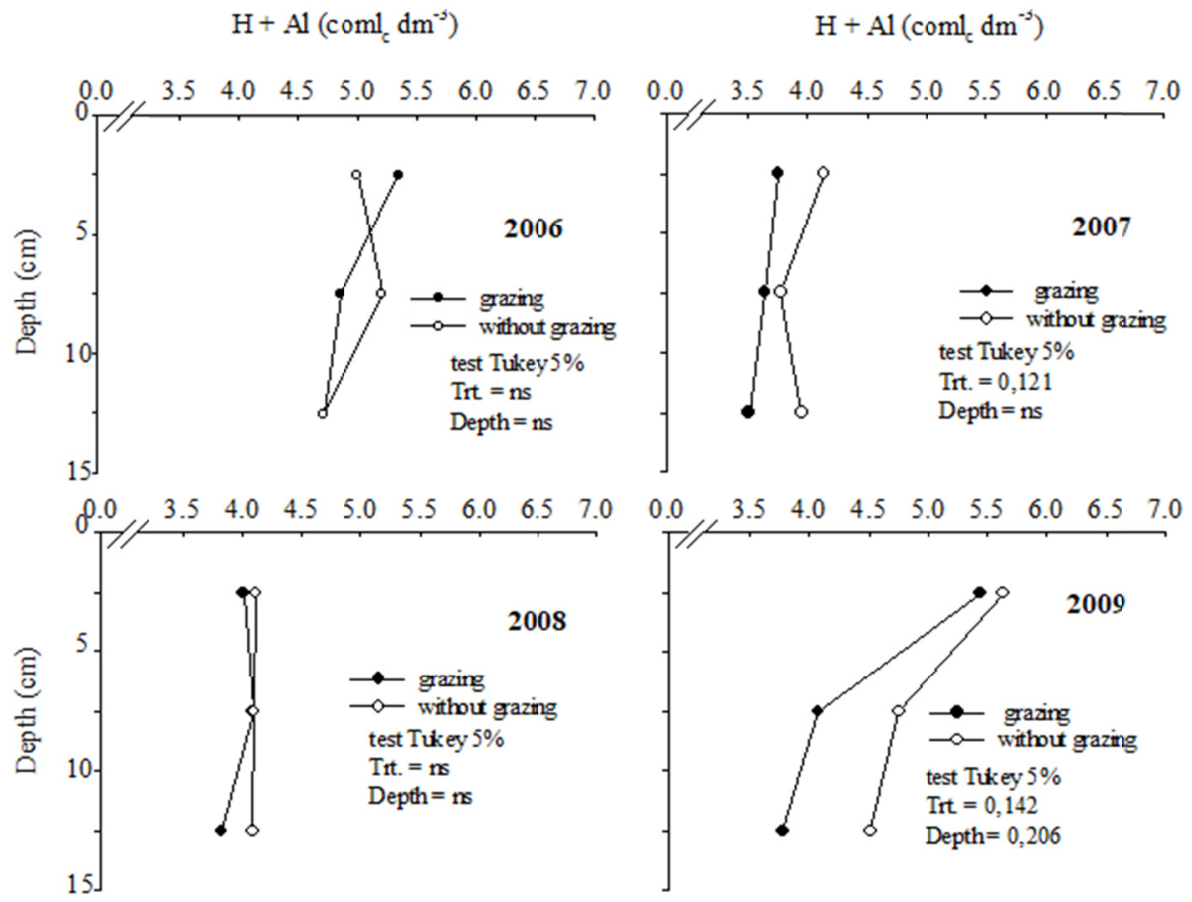

Figure 4. Potential acidity (cmolc $\mathrm{dm}^{-3}$ ) in a Crop-Livestock System according to whether or not grazing (Trt) was used in winter and depth $(0-5,5-10$ and 10-15 cm) in the years 2006, 2007, 2008 and 2009. Guarapuava, PR

Table 1. $\mathrm{pH}$ values in $\mathrm{CaCl}_{2}$ in a crop-livestock integration system with and without grazing in the winter depths of $0-5 ; 5-10 ; 10-15 \mathrm{~cm}$ in the years of 2006, 2007, 2008 and 2009. Guarapuava, PR

\begin{tabular}{|c|c|c|c|c|c|c|c|c|c|c|c|c|}
\hline \multicolumn{13}{|c|}{$\mathrm{pH}\left(\mathrm{CaCl}_{2}\right) \mathrm{CaCl}_{2}$} \\
\hline & \multicolumn{3}{|c|}{2006} & \multicolumn{3}{|c|}{2007} & \multicolumn{3}{|c|}{2008} & \multicolumn{3}{|c|}{2009} \\
\hline & Grazing & w/o grazing & Mean & Grazing & w/o grazing & Mean & Grazing & w/o grazing & Mean & Grazing & w/o grazing & Mean \\
\hline $0-5$ & 5.25 & 5.23 & $5.24 \dagger$ & 5.53 & 5.48 & $5.51 \mathrm{a}$ & 5.52 & 5.44 & $5.48 \mathrm{a}$ & 4.82 & 4.85 & $4.83 \mathrm{a}$ \\
\hline $5-10$ & 5.27 & 5.16 & $5.21 \mathrm{a}$ & 5.68 & 5.46 & $5.57 \mathrm{a}$ & 5.59 & 5.48 & $5.53 \mathrm{a}$ & 5.43 & 5.25 & $5.34 \mathrm{~b}$ \\
\hline $10-15$ & 5.29 & 5.22 & $5.25 \mathrm{a}$ & 5.63 & 5.43 & $5.53 \mathrm{a}$ & 5.64 & 5.50 & $5.57 \mathrm{a}$ & 5.56 & 5.50 & $5.53 \mathrm{c}$ \\
\hline Mean & $5.27 \mathrm{~A} \dagger$ & $5.20 \mathrm{~A}$ & & $5.62 \mathrm{~A}$ & $5.46 \mathrm{~B}$ & & $5.58 \mathrm{~A}$ & $5.47 \mathrm{~A}$ & & $5.27 \mathrm{~A}$ & $5.20 \mathrm{~A}$ & \\
\hline
\end{tabular}

Note. $\dagger$ Averages followed by different upper case letters in the row and lower case letters in the column differ (P $<0.05$ ) by the Tukey test. $\$$ NS, not significant at 0.05 probability of error. $*$ Significant at a level of 0.05 ; ** Significant at a level of 0.01 .

Considering that the deposition of excrements with animal origin promotes greater microbial activity of the soil, generating a large amount of biopores in the soil (Santos et al., 2011), that contributes for the displacement of calcareous particles, favoring the correction of soil acidity in subsurface (Flores et al., 2008). Another possible factor is the mechanical displacement of calcareous particles or even nutrients through the channels formed by dead roots, since in grazing the proportion of roots tends to be larger than without grazing (Souza et al., 2008).

Following the $\mathrm{pH}$ values, we have observations of similar behavior with SB values in depth, especially in the year 2009.SB was uniform in the year of 2006, implantation of the experiment and beginning of collections (Figure 5). In 2007 and 2009, higher SB values were observed for areas with grazing and differences in depth of sampling only in the first two years. This suggests better conditions in the presence of $\mathrm{K}, \mathrm{Ca}$ and $\mathrm{Mg}$ cations with grazing, not only in the superficial layer, but up to $15 \mathrm{~cm}$ deep. This characteristic can be justified by the concentrations of $\mathrm{Ca}$ found in these soils, due to the higher accumulation of $\mathrm{K}$ in the superficial layer (Figure 1) and the uniformity of $\mathrm{Ca}$ distribution in the soil profile up to $15 \mathrm{~cm}$ deep. 
Sum of bases $\left(\operatorname{coml}_{\mathrm{c}} \mathrm{dm}^{-3}\right)$

Sum of bases $\left(\mathrm{coml}_{\mathrm{c}} \mathrm{dm}^{-3}\right)$

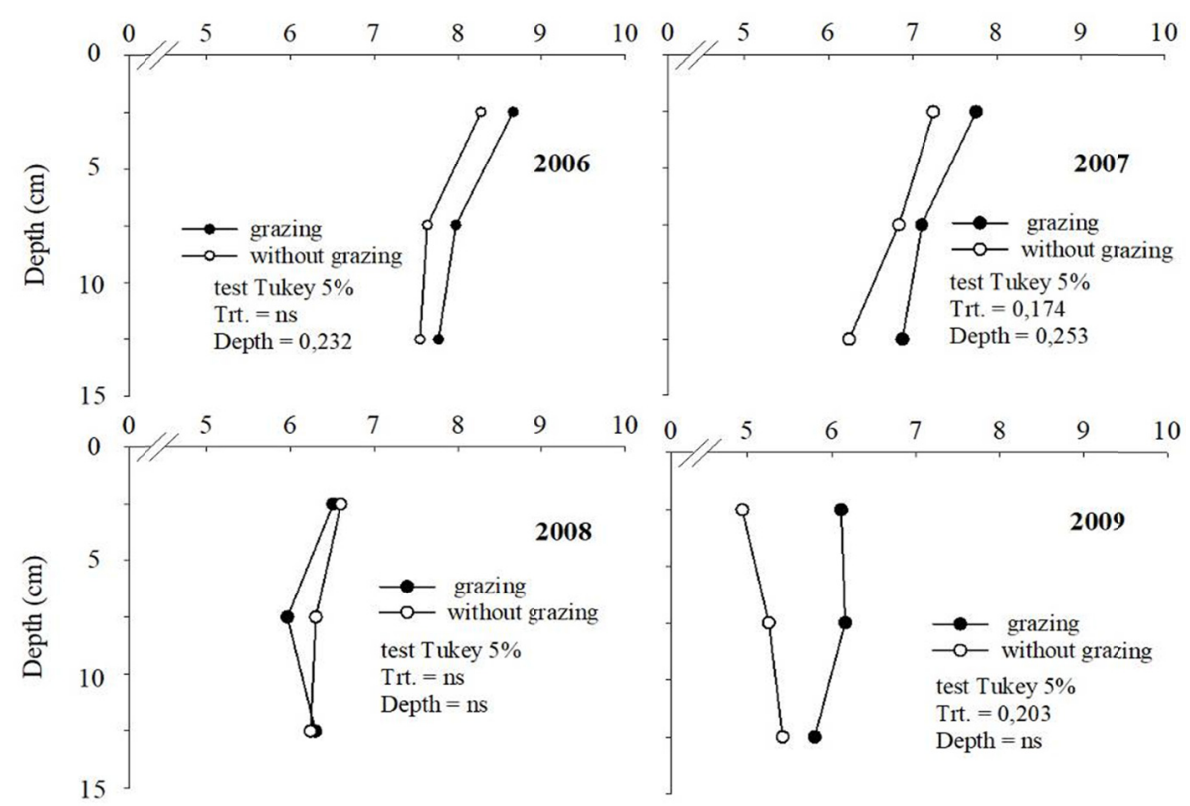

Figure 5. Sum of bases $\left(\mathrm{cmolc} \mathrm{dm}^{-3}\right)$ in a Crop-Livestock System farming according to whether or not grazing

(Trt) was used in winter and depth (0-5, 5-10 and 10-15 cm) in the years 2006, 2007, 2008 and 2009.

Guarapuava, PR

Ca contents presented significant differences only at the depth of $5-10 \mathrm{~cm}$ in the beginning of the experiment (2006) and decreased from 2007 on, which is characterized by the extraction of nutrients held in the year prior to 2006 when growing corn for silage of the whole plant (Figure 6).

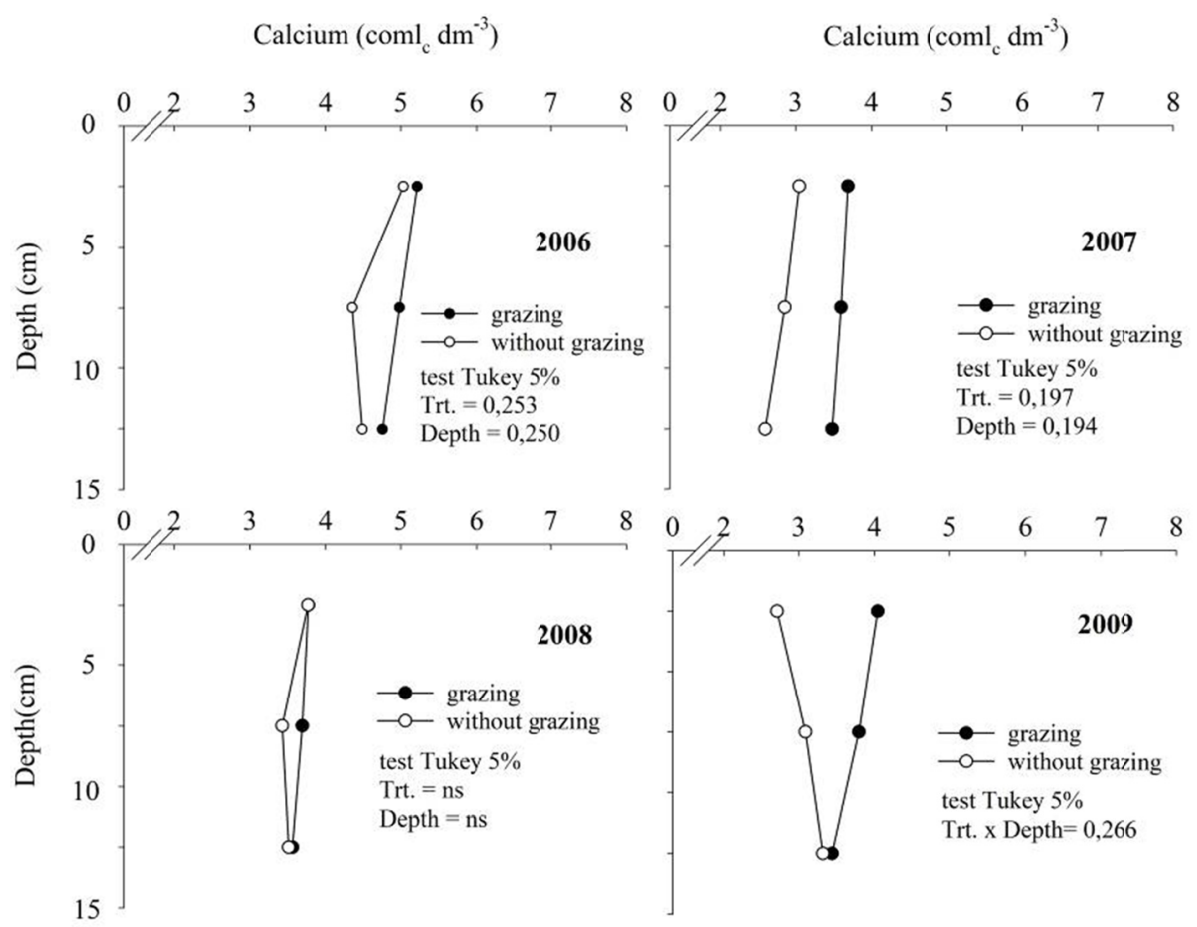

Figure 6. Concentration of $\mathrm{Ca}\left(\mathrm{cmol}_{\mathrm{c}} \mathrm{dm}^{3}\right)$ in Crop-Livestock System according to whether or not grazing (Trt) was used in winter and depth $(0-5,5-10$ and 10-15 cm) in the years 2006, 2007, 2008 and 2009. Guarapuava, PR 
However, Ca concentration amounts are higher in overgrazing areas in the two years of evaluation (2007 and 2009), both after bean cultivation. The supply of minerals to the animals during the overgrazing period and their return via feces and urine to these areas seems to be contributing to an improvement in the availability of $\mathrm{Ca}$ in the soil (Figure 6). The highest concentrations of $\mathrm{Ca}$ in grazing areas are in agreement with those found by Flores et al. (2008) while working with surface liming observed higher concentrations of $\mathrm{Ca}$ in the areas with grazing after 24 months of calcareous application and positive effect of the animal on soil correction as for calcareous.

Very close $\mathrm{Ca}$ contents were observed between the sampled depths, characterizing Ca movement in the soil profile. This is due to the release of organic acids of low molecular weight from the decomposition of organic residues, which act as organic binders, which is also suggested from the decomposition of animal feces (Miyazawa et al., 1993; Franchini et al., 2000).

The $\mathrm{Ca}$ (Figure 7) when in excess in relation to the $\mathrm{Mg}$ in the soil solution tends to impair the absorption of the latter, in the same way the excess of $\mathrm{Mg}$ impairs the absorption of $\mathrm{Ca}$, having same observations for the $\mathrm{K}$ (Malavolta et al. 1997). In this sense, Ca contents, although with differences, are very close at the beginning of the experiment (2006). Like other nutrients, its concentration in the soil decreased from the year 2007, which is characterized by the extraction of nutrients held in the year prior to 2006 when corn was grown by whole plant silage.

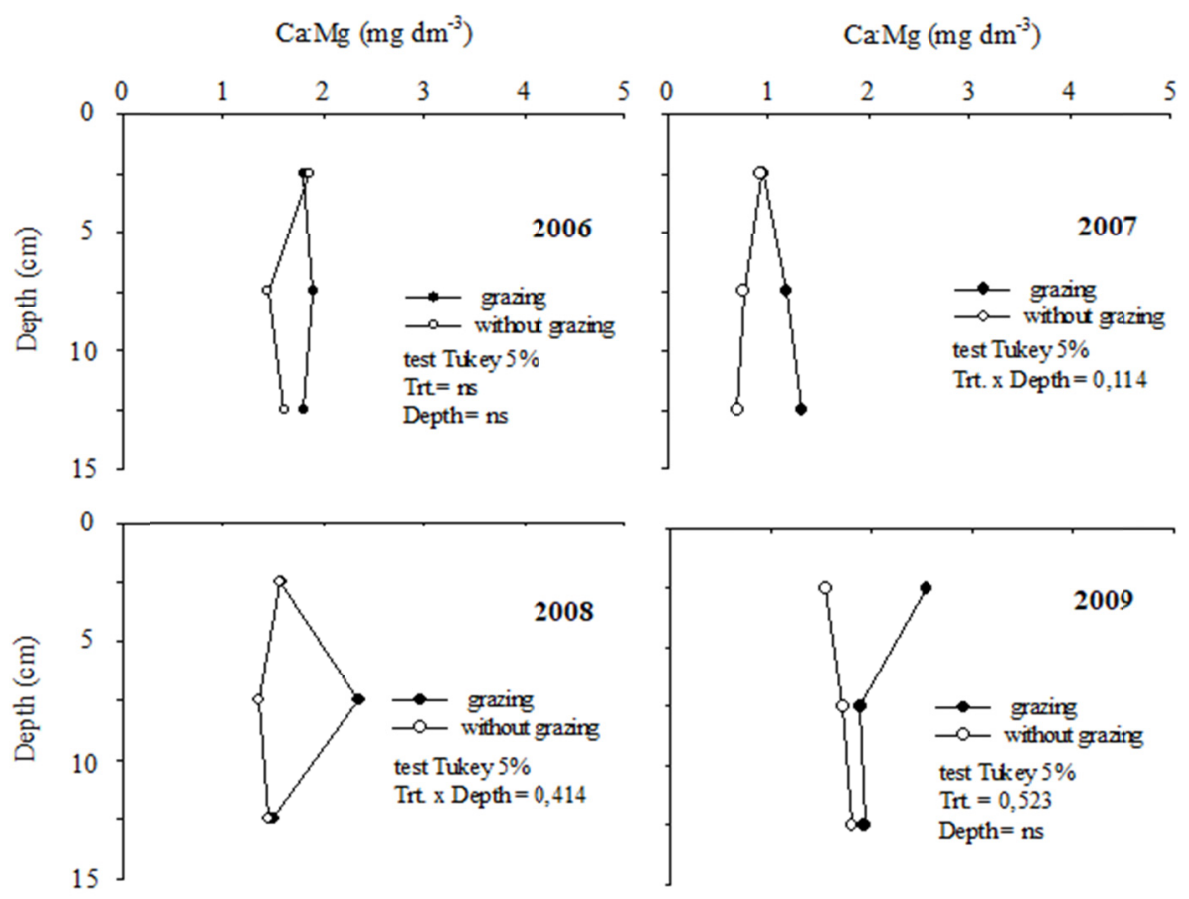

Figure 7. Ca: $\mathrm{Mg}\left(\mathrm{mg} \mathrm{dm}^{-3}\right)$ ratio in a Crop-Livestock System farming according to whether or not grazing (Trt) was used in winter and depth (0-5, 5-10 and 10-15 cm) in the years 2006, 2007, 2008 and 2009. Guarapuava, PR

The Ca: Mg ratio (Figure 7) in the years 2008 and 2009 was increased by overgrazing. Inappropriate relations of $\mathrm{Ca}: \mathrm{Mg}$ in the soil results in a nutritional imbalance, which can induce plant deficiencies and decrease in growth and productivity (Rosolem et al., 1984). High Ca: $\mathrm{Mg}$ ratio may cause an antagonistic effect between $\mathrm{Ca}$ and $\mathrm{Mg}$ uptake by the plant, Hernandez et al. (1998) observed lower yields of corn dry matter with $\mathrm{Ca}$ : Mg ratio higher than 3:1, better yields when ratio was between $2: 1$ and 3:1, agreeing with the results of the present study based on overgrazing after four years of the animal into the system. Oliveira and Parra (2003) did not observe variation in bean yield under different $\mathrm{Ca}$ : $\mathrm{Mg}$ ratios.

The last application of calcareous was done in a superficial and without incorporation, and it is observed that the contents of $\mathrm{Ca}$ and $\mathrm{Mg}$ are uniform at depths evaluated from 0-15 according to studies (Caires et al., 2003; Flores et al., 2008) that demonstrate the effectiveness of surface liming with increase in the presence of overgrazing sheep. 


\section{Conclusions}

Winter grazing with sheep did not characterize extractions and losses of K. P and Ca in the integration system for livestock farming under direct planting system. On the contrary, Ca concentrations are increased with grazing, even in deeper layers of the soil.

After corn cultivation $\mathrm{K}$ concentrations are lower in the soil in relation to the bean cultivation. Potential soil acidity $(\mathrm{H}+\mathrm{Al})$ was higher in areas with no grazing in depth of $0-15 \mathrm{~cm}$, suggesting that the animal in the system determines better conditions of the chemical attributes $\mathrm{K}, \mathrm{Ca}$ and $\mathrm{H}+\mathrm{Al}$.

\section{References}

Alvares, C. A., Stape, J. L., Sentelhas, P. C., De Moraes Gonçalves, J. L., \& Sparovek, G. (2013). Köppen's climate classification map for Brazil. Meteorologische Zeitschrift, 22(6), 711-728. https://doi.org/10.11 27/0941-2948/2013/0507

Andreolla, V. R. M. (2010). Integração lavoura-pecuária: atributos fisicos do solo e produtividade das culturas do feijão e milho (p. 139, Tese (Doutorado) Universidade Federal do Paraná, Curitiba).

Assmann, T. S., Júnior, P. R., Morae, S, A., Assmann, A. L., Koehler, H. S., \& Sandini, I. (2003). Rendimento de milho em área de integração lavoura-pecuária sob o sistema plantio direto, em presença e ausência de trevo branco, pastejo e nitrogênio. Revista Brasileira de Ciência do Solo, 27, 675-68. https://doi.org/ $10.1590 / \mathrm{S} 0100-06832003000400012$

Balbinot, Jr., A. A., Moraes A., Pelissari, A., Dieckow, J., \& Veiga, M. (2008). Formas de uso do solo no inverno e sua relação com a infestação de plantas daninhas em milho (Zea mays) cultivado em sucessão. Planta Daninha, 26, 569-576. https://doi.org/10.1590/S0100-83582008000300012

Caires, E. F., Banzatto, D. A., \& Fonseca, A. (2000). Calagem na superfície em sistema plantio direto. R. Bras. Ci. Solo, 24, 161-169.

Caires, E. F., Banzatto, D. A., \& Fonseca, A. F. (2000). Calagem na superfície em sistema de plantio direto. Revista Brasileira de Ciência do Solo, 24, 161-169. https://doi.org/10.1590/S0100-06832000000100018

Caires, E. F., Blum, J., Barth, G., Garbuio, F. J., \& Kusman, M. T. (2003). Alterações químicas do solo e resposta da soja ao calcário e gesso aplicados na implantação do sistema plantio direto. Revista Brasileira de Ciência do Solo, 27, 275-286.

Castoldi, G., Freiberger, M. B., Castoldi, G., \& Costa, C. H. M. (2012). Manejo da adubação em sistema plantio direto. Revista Trópica-Ciências Agrárias e Biológicas, 6(1), 62-74.

Cavalcante, E. G. S., Alves, M. C., Pereira, G. T., \& Souza, Z. M. (2007). Variabilidade espacial de MO, P, K e CTC do solo sob diferentes usos e manejos. Ciência Rural, 37, 394-400. https://doi.org/10.1590/ S0103-84782007000200015

Cavalcante, M. A. B. (2011). Reciclagem de excreções animais na pastagem.

Ceretta, C. A., Basso, C. J., Diekow, J., Aita, C., Pavinato, P. S., Vieira, F. C. B., \& Vendrusculo, E. R. O. (2002). Nitrogen fertilizer split-application for corn in notill succession to black oats. Sci. Agric., 59, 549-554. https://doi.org/10.1590/S0103-90162002000300021

Ciotta, M. N., Bayer, C., Ernani, P. R., Fontoura, S. M. V., Wobeto, C., \& Albuquerque, J. A. (2004). Manejo da calagem e os components da acidez de Latossolo Bruno em Plantio direto. R. Bras. Ci. Solo, 28, 317-326. https://doi.org/10.1590/S0100-06832004000200010

EMBRAPA (Empresa Brasileira de Pesquisa Agropecuária). (2013). Sistema Brasileiro de Classificação de Solos (3rd ed.). EMBRAPA-SPI, Brasília.

Entz, M. H., Baron, V. S., Carr, P. M., Meyer, D. W., \& Mccaughey, P. W. (2002). Potential of forages to diversify cropping systems in the Northern Great Plains. Agronomy Journal., 94, 240-250. https://doi.org/ 10.2134/agronj2002.0240

Ferreira, E. V. O., Anghinoni, I., Andrighetti, M. H., Martins, A. P., \& Carvalho, P. C. F. (2011). Ciclagem e Balanço de Potássio e Produtividade de Soja na Integração Lavoura-Pecuária sob Semeadura Direta. $R$. BRas. Ci. Solo, 35, 161-169.

Ferreira, E. V. O., Anghinoni, I., Carvalho, P. C. F., Costa, S. E.V . G. A., \& Cao, E. G. (2009). Concentração de potássio do solo em sistema de integração lavoura-pecuária em plantio direto submetido a intensidades de 
pastejo. Revista Brasileira de Ciência do Solo, 33, 1675-1684. https://doi.org/10.1590/S0100-068320 09000600016

Flores, J. P. C., Cassol, L. C., Anghinoni, I., \& Carvalho, P. C. F. (2008). Atributos químicos do solo em função da aplicação superficial de calcário em sistema de integração lavoura-pecuária submetido a pressões de pastejo em plantio direto. Revista Brasileira de Ciência do Solo, 32, 2385-2396. https://doi.org/10.1590/ S0100-06832008000600017

Fontaneli, R. S., Santos, H. P., Fontaneli, R. S., Hentz, P., \& Lehmen, R. I. (2011). Forrageiras para integração lavoura-pecuária na região sul-brasileira. Synergismus Scyentifica, 6(2).

Franchini, J. C., Borkert, C. M., Ferreira, M. M., \& Gaudêncio, C. A. (2000). Alterações na fertilidade do solo em sistemas de rotação de culturas em semeadura direta. Revista Brasileira de Ciência do Solo, 24, 459-467. https://doi.org/10.1590/S0100-06832000000200022

Hernandez, R. J., \& Silveira, R. I. (1998). Efeitos da saturação por bases, relações Ca:Mg no solo e níveis de fósforo sobre a produção de material seco e nutrição mineral do milho (Zea mays L.). Scientia AgríCola, 55, 79-85. https://doi.org/10.1590/S0103-90161998000100014

Kayser, M., \& Isselstein, J. (2005). Potassium cycling and losses in grassland systems: A review. Grass and Forage Science, 60, 213-224. https://doi.org/10.1111/j.1365-2494.2005.00478.x

Malavolta, E., Vitti, G. C., \& Oliveira, S. A. (1997). Avaliação do estado nutricional de plantas: Princípios e aplicações (p. 319). Piracicaba: Potafos.

Miyazawa, M., Pavan, M. A. (1993). Efeito de material vegetal na acidez do solo. Revista Brasileira de Ciência doSolo, 17, 411-416.

Nunes, R. S., Sousa, D. M. R., Goedert, W. J., \& Vivaldi, L. J. (2011). Distribuição De Fósforo No Solo Em Razão Do Sistema De Cultivo E Manejo Da Adubação Fosfatada. R. Bras. Ci. Solo, 35, 877-888. https://doi.org/10.1590/S0100-06832011000300022

Oliveira, E. L., \& Parra, M. S. (2003). Resposta do feijoeiro a relações variáveis entre cálcio e magnésio na capacidade de troca de cátions de Latossolos. Revista Brasileira Ciência do Solo, 27, 859-866. https://doi.org/10.1590/S0100-06832003000500010

Parente, T. L., Lazarini, E., Caioni, S., Souza, L. G. M., Pivetta, R. S., \& Bossolani, J. W. (2016). Potássio em cobertura no milho e efeito residual na soja em sucessão1. Revista Agro@mbiente On-line, 10(3), 193-200. https://doi.org/10.18227/1982-8470ragro.v10i3.3258

Pariz, C. M., Andreotti, M., Buzetti, S., Bergamaschine, A. F., Ulian, N. A., Furlan, L. C., ... Cavasano, F. A. (2011). Straw decomposition of nitrogen-fertilized grasses intercropped with irrigated maize in an integrated crop-livestock system. R Bras Ci Solo. https://doi.org/10.1590/S0100-06832011000600019

Rosolem, C. A., Machado, J. K., \& Brinholi, O. (1984). Efeito das relações $\mathrm{Ca} / \mathrm{Mg}, \mathrm{Ca} / \mathrm{K}$ e $\mathrm{Mg} / \mathrm{K}$ do solo na produção de sorgo sacarino. Pesquisa Agropecuária Brasileira, 19, 1443-1448.

Sandini, I. E., Moraes, A., Pelissari, A., Neumann, M., Falbo, M. K., \& Novakowiski, J. H. (2011). Efeito residual do nitrogênio na cultura do milho no sistema de produção integração lavoura-pecuária. Ciência Rural, 41(8), 1315-1322. https://doi.org/10.1590/S0103-84782011005000099

Santos, G. G., Marchão, R. L., Silva, E. M., Silveira, P. M., \& Becquer, T. (2011). Soil physical quality in Integrated crop-livestock systems. Pesq. Agropec. Bras, 46(10).

Santos, H. P., Fontaneli, R. S., Tomm, G. O., \& Spera, S. T. (2003). Efeito de sistemas de produção mistos sob plantio direto sobre fertilidade do solo após oito anos. Revista Brasileira de Ciência do Solo, 27, 545-552. https://doi.org/10.1590/S0100-06832003000300016

Santos, M. M., Galvão, J. C. C., Silva, I. R., Miranda, G. V., \& Finger, F. L. (2010). Épocas de aplicação de nitrogênio em cobertura na cultura do milho em plantio direto, e alocação do nitrogênio $(15 \mathrm{~N})$ na planta. $R$. Bras. Ci. Solo, 34, 1185-1194. https://doi.org/10.1590/S0100-06832010000400018

SAS (Statistical Analysis System). (2002). User's guide. Cary:SAS Institute.

Sidiras, N., \& Pavan, M. A. (1985). Influência do sistema de manejo do solo no seu nível de fertilidade. Revista Brasileira de Ciência do Solo, 9, 249-254. 
Souto, M. S. (2006). Pastagem de aveia e azevém na integração lavoura-pecuária: Produção de leite e caracteristicas do solo (80f, Dissertação (Mestrado), Programa de Pós-Graduação em Agronomia-Produção Vegetal, Setor de Ciências Agrárias, Universidade Federal do Paraná, Curitiba, Brazil).

Souza, E. D., Costa, S. E. V. G. A., Lima, C. V. S., Anghinoni, I., Meurer, Ce. J., \& Carvalho, P. C. F. (2008). Carbono orgânico e fósforo microbiano em sistema de integração agricultura-pecuária submetido a diferentes intensidades de pastejo em plantio direto. Revista Brasileira de Ciência do Solo, 32, 1273-1282. https://doi.org/10.1590/S0100-06832008000300035

Vendramini, J. M. B., Dubeux, J. R., \& Silveira, M. L. (2014). Nutrient cycling in tropical pasture ecosystems. Rev. Bras. Ciênc. Agrár. Recife, 9(2), 308-315. https://doi.org/10.5039/agraria.v9i2a3730

Whitehead, D. C. (2000). Nutrient elements in grassland: Soil-plant-animal relationships Int., Wallingford CAB. https://doi.org/10.1079/9780851994376.0000

Zanão Junior, L. A., Lana, R. M. Q., Guimarães, E. C., \& Pereira, J. M. A. (2010). Variabilidade espacial dos teores de macronutrientes em latossolos sob sistema de plantio direto. Revista Brasileira de Ciência do Solo, 34, 389-400. https://doi.org/10.1590/S0100-06832010000200012

\section{Copyrights}

Copyright for this article is retained by the author(s), with first publication rights granted to the journal.

This is an open-access article distributed under the terms and conditions of the Creative Commons Attribution license (http://creativecommons.org/licenses/by/4.0/). 